DIVERGING BY GENDER:

Syrian Refugees' Divisions of Labor and Formation of Human Capital in the United States

\title{
HEBA GOWAYED
}

\section{COLUMBIA UNIVERSITY, UNITED STATES}

In this article, I examine how Syrian refugee men and women shifted their household divisions of labor in their initial years of resettlement in the United States. I combine and extend relational approaches from gender theory and economic sociology to examine how men and women's behaviors shifted, the resources engendered by behavioral shifts, and how they interpreted and compensated for new behaviors and resources. I show that shifts in Syrian household divisions of labor occurred at the intersection of inequalities in social policies, labor-markets and households. Due to limited social assistance, the refugee families needed to earn an income within months of their arrival. The Syrian men entered the labor-market, keeping with a breadwinning expectation for their labor, but could only access menial jobs that limited their time and opportunity learn English. Women, meanwhile, did not enter the labor-market full time, and could attend English classes. By observing this divergence in men and women's language learning, I theorize human capital as a gendered outcome of household divisions of labor.

Keywords: gender, forced migration, human capital, relational work, social policy

AUTHOR'S NOTE: I thank Viviana Zelizer, Mitchell Duneier, Margaret Frye, Nicholas Occhiuto, Sharon Cornelissen, Rene Almeling, the attendees of the Chicago Ethnography Incubator, and particularly Kristen Schilt, as well as the journal editors and reviewers, for feedback on earlier drafts of this paper. I thank the Horowitz Foundation and the National Science Foundation for funding this project. Finally, I thank the project participants for their time and generosity. Correspondence concerning this article should be addressed to Heba Gowayed, Columbia University, 601D Knox Hall, New York, NY 10027, USA, email: hyg2103@columbia.edu. 
Survey research that has examined household divisions of labor among immigrant men and women has not found drastic shifts between countries of origin and destination: though women may take on more paid labor, men remain primary breadwinners (Blau, Kahn, and Papps 2011; Frank and Hou 2015). Gender and immigration studies, however, find that divisions of household labor are reorganized and contested between men and women in myriad ways, even if there are not drastic shifts in hours of paid and unpaid labor (Dreby 2006; Hondagneu-Sotelo 2013; Pessar and Mahler 2003). Understudied in this literature, and in the immigration literature as a whole, however, is what happens in the initial years after arrival when cultural meanings developed in one context first interact with the demands of another.

This study addresses this gap by drawing on ethnographic data of Syrian refugee families in their initial two years of resettlement in the United States. I combine relational approaches from gender theory and economic sociology to examine three aspects of shifting household divisions of labor (West and Zimmerman 1987; Zelizer 2012). First, I examine how behaviors shift—or how the content of men and women's labor adjusts to the resources and constraints offered in a new context. Second, I examine how new behaviors engender new resources for women and men. Third, I examine how cultural meanings—expectations for how men and women behave - shape the way that these behaviors and resources are interpreted. Building on literature in gender and immigration and gender and work, I argue that all three of these aspects occur at the intersection of three sets of inequalities: those within households, within labormarkets, and in social policies (Damaske 2011; Flippen 2014).

I find that Syrian men entered menial jobs due to the inequality of the U.S. post-industrial economy, the lack of social service support available to resettled families, and cultural expectations within families for men to be primary breadwinners. Men, due to the nature of the 
jobs they could access, lacked the time to attend English classes. Women, by contrast, entered the labor-market part-time when they did, and had the time to attend English class at the resettlement agency. Through this finding, I theorize human capital as a gendered outcome of household divisions of labor. I also show that shifts in behaviors as well as new resources-of human capital and cash earned by women — were interpreted through cultural meanings about men and women's labor.

\section{RELATIONAL APPROACHES TO HOUSEHOLD DIVISIONS OF LABOR}

To systematically examine the complexity of men and women's adjustment of household divisions of labor in immigration, I bridge and extend two literatures-relational approaches in gender theory and relational approaches in economic sociology — which examine relationships as sites of meaning-making about gender and economic life respectively. First, a relational approach from gender theory holds that masculinities and femininities are constituted within an institutional setting and within the household - where men typically have power and resource advantage (Connell and Messerschmidt 2005). According to this theory, because gender interactions are constrained by context, a change in that context should entail a change in way that gender is "done" (Pessar and Mahler 2003; West and Zimmerman 2009). These shifts in "doing" gender, however, do not necessarily mean departures from cultural meanings about men and women's labor. Masculinities and feminities can be retained—-though often in adjusted forms-across contexts (England et al. 2010).

Second, the relational approach from economic sociology focuses on economic action, examining how gender meanings are either maintained or changed in transactions. This approach holds that economic action between partners represents, reinforces, and constitutes interpersonal 
relationships. Household economic transactions, including divisions of labor, reflect the meaning men and women hold about themselves and their marriage. People do "relational work" to match those meanings to the right kind of economic transactions (Zelizer 2012). Difficult and emotional situations emerge when economic partners are unable to perform transactions in ways that are meaningful to them, or when relational work fails (Bandelj 2012; Tilly 2006). Economic media (such as money) is a part of this negotiation. It is earmarked, or categorized and used, in ways that reflect broader notions about a relationship between partners (Zelizer 1997).

Together, these relational approaches clarify that within the constraints or opportunities offered in a new context, men and women's behaviors will shift vis-à-vis one another, but there will also be attempts to reconcile these shifts with preexisting meanings about how they should behave as women and men. Studies confirm that as partners move across borders, together or separate from one-another, cultural meanings about being a mother, father, or spouse developed in countries of origin continue to shape emotions and behaviors (Dreby 2006). Where behaviors change too far, compensatory action ensues. For instance, studies show that women entering workplaces, as immigrants or not, continue to shoulder the responsibility for unpaid work, leading to a "double shift" (Blair-Loy 2009; Hochschild 1989). The maintenance of gendered cultural expectations, despite shifts in behavior, can result in women's diminished resources such as decision-making power within households, or their diminished control over cash (Espiritu 2001; Ferree 1979).

Drawing on these findings, I extend the relational approach to examine how adjusting divisions of labor can matter for access to resources. As men and women enter new settings and adjust their labor vis-à-vis one another, they spend their time in new ways. Some studies have shown that women can gain resources as they interact with new social networks, and have access 
to new sets of social services (Hondagneu-Sotelo 1999; Kibria 1993). Others studies have argued that immigration depletes women's resources as they experience the intersection of household and labor-market inequalities (Parrado and Flippen 2005; Parreñas 2001). While these literatures show different kinds of outcomes, studies also clarify that these gains and losses can be experienced simultaneously; inequality is not all-or-nothing (Mahler and Pessar 2006).

In this study, I examine human capital as a resource generated through adjusting divisions of labor in immigration. Human capital — a measure of skills and capacities that are productive in a labor-market - has long been examined as a determinant of immigrant's economic trajectories (Becker 1985; Portes and Rumbaut 2014). Language, a type of human capital, is identified as crucial for immigrant labor-market involvement, and for its ability to facilitate day to day life (Nawyn et al. 2012). Rather than examining language solely as a determinant of immigrant outcomes, I look at how language is acquired by Syrians, who did not speak English when they arrived in the U.S. I argue that how men and women divided and understood their labor determined who had the opportunity to learn. Following, I theorize human capital as a gendered outcome of the relational management of divisions of household labor. I also argue that how families divided household labor, and the ramifications of that division for access to resources, were products of their receiving context. The following section describes the contextual inequalities that drove these relational processes.

\section{CONTEXT AND HOUSEHOLD DIVISIONS OF LABOR}

Early work on gender and immigration focused on inequalities within the family, neglecting how gender is done in social networks, labor markets and laws of receiving contexts (Kibria 1993; Pessar 1986). Meanwhile, immigration literature that examined these elements of context did not 
examine them as gendered (Portes and Rumbaut 2014). Recent studies combine insights from these literatures. They show that social networks that facilitate labor market access for men may restrict participation of women by reinforcing cultural norms (Allen 2009). They capture how, in the post-industrial economy, immigrants increasingly occupy jobs characterized by a decline in living wages and a rise in nonstandard work, but immigrant women also face gender essentialism, a lack of support for childcare, and less pay for equal work (Flippen 2014; Kalleberg 2011). They also highlight how transnational mobilities, and legal status, are themselves experienced differently by women and men (Golash-Boza and Hondagneu-Sotelo 2013; Mahler and Pessar 2006; Parreñas 2001).

Recent studies from the gender and immigration and gender and work literatures examine how these elements of context intersect. A study of Latinas found that their legal status, family make-up, and English ability combined to determine their labor market supply in North Carolina (Flippen 2014). Another study found that while all women cite familial obligations as reasons for dropping out of the workplace, low-income women lack organizational support, and feel demeaned at work, and thus exit the labor market at a higher rate than high income women (Damaske 2011). These studies, while looking only at the experiences of women, show how the nature of the workplace and policies shape their labor market participation and pathways.

I build on these studies by examining the experiences of refugee men and women as they shifted their division of labor at the intersection social policy, labor market, and household inequalities. In the U.S. the refugee resettlement program aims for "self-sufficiency," or nonreliance on government assistance (United States Congress 1980). Refugees are offered welfare, Temporary Assistance for Needy Families (TANF), a program otherwise available only to lowincome Americans. TANF limits cash, and monitors recipient activities, to push labor market 
entry. This push towards the labor-market discounts both care work and paid work done from home, disproportionately performed by women (Shola Orloff 2009; Silver 1993). Faced with this policy context, refugees need to enter the labor market within 3 to 6 months after their arrival, when their rent assistance from the resettlement agency would end. By contrast, the Canadian system offers refugees a full year of cash assistance (Government of Canada 2016; Halpern 2008). As the Syrian refugees in this study did not have the opportunity to learn English or meaningfully translate their skills prior to labor market entry, the jobs available to them featured low wages, long hours and shift work. Men took on these jobs, fulfilling breadwinning expectation, whereas women initially stayed out of the labor-market, which resulted in women being able to attend English class, whereas men could not. This counterintuitive finding, where a confirmation of gender expectations for men and women's labor leads to a positive outcome for women in terms of language learning, is a product of the context in which men and women performed their labor.

\section{METHODS}

This study is part of an ethnographic project conducted from October 2015 to 2017 that followed 18 Syrian refugee families in their resettlement in Connecticut. It is estimated that more than 5 million refugees were externally displaced as part of the Syrian War that began in 2011. Less than 1 percent were offered resettlement in countries, such as the U.S., where they would be offered full legal rights (UNHCR 2016). In the 2015 fiscal year, 10,000 Syrian refugees were resettled across the U.S., going all over the country (Park and Omri 2016). While each state has its own TANF maximums (Edin and Shaefer 2015), and while each resettlement agency has 
different policies and offers different sets of services for refugees, self-sufficiency policy impacts all newly arrived refugees as it is the federal strategy for resettlement.

The Syrian refugee families in this study began to resettle in the summer of 2015. The time of their arrival explains why the respondents of this study are a relatively homogenous group. They all fled Syria in 2012 or early 2013, as they were all Sunni Muslims living in areas like Homs, Allepo, Daraa, Latakia, and Damascus that were attacked in these early stages of the war (Khazan 2012). The men and women identify as members of the Syrian middle class and had resources to flee Syria at this time. Included in this study are 17 families and one single man who was resettled when he was an unaccompanied minor. Of the 17 families, all are dualheaded, except for one woman who was widowed in Jordan and all had at least one child. The women's educational levels ranged from illiterate to some college, with most women leaving school in the middle-school level. The men, meanwhile, were more likely to be illiterate, and none had finished high school. The men worked in Syria, whereas the women did not (see Table 1).

Most of the families in this study fled initially to Jordan, with three going to Turkey which was closer to them as they were from Aleppo. Within their first year in each country, they received a phone call from the United Nations Higher Council for Refugees (UNHCR) inviting them to apply for resettlement to the U.S. They agreed to apply and underwent 18-24 months of vetting which included interviews and biometric screenings. The refugees began to arrive in the U.S. in July 2015, with the first 15 -both to the city in which this study is conducted, and in my study — arriving by February 2016. I followed the resettlement of these respondents for their first 20-27 months in the U.S. 3 families related to these first 15 arrived in the summer of 2016. I included these families during their initial 14 to 15 months of resettlement. 
TABLE 1: Sample Description by Family and Pseudonym

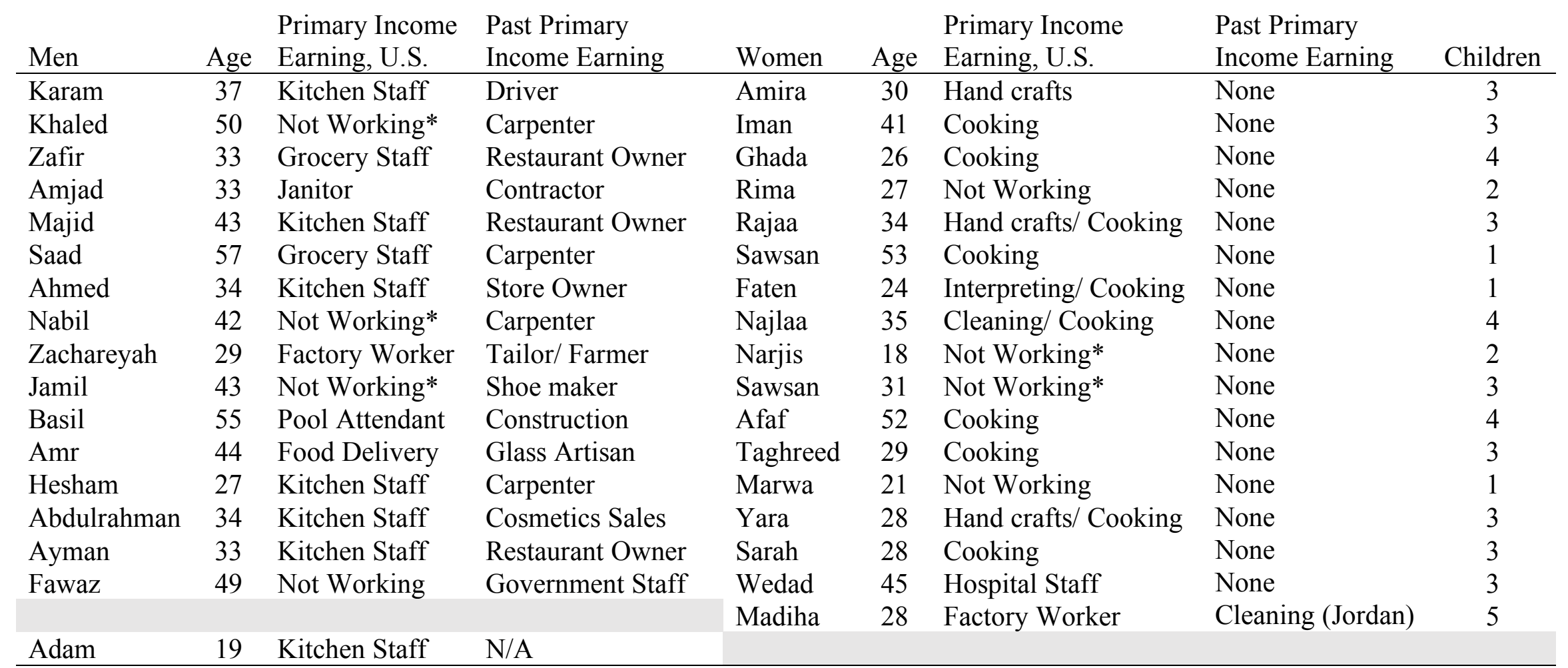

NOTES: "Primary Income Earning, U.S." is the primary income-earning activity men and women performed in the period of this study.

"Cooking" is the selling of sweets, cookies and catering meals or dinners.

*Reason for not working is due to chronic illness/disabilities either personal or within the household. 
My ethnographic work was conducted in Arabic, a language in which I am fluent. I recorded my field notes, the only source of data for this paper, each evening after my field work. In some cases, I wrote down memorable quotes after they were said using my phone notes function. Initially, I gained entrée to this site by describing my research to the head of the local resettlement agency, and volunteering to provide Arabic-English interpretation. My initial interaction with refugees was often on their day of arrival, with members of the resettlement agency staff, in my role as interpreter. Within their initial weeks, I described my project, asked for consent, and promised confidentiality.

My identity as an Egyptian-American woman facilitated this entrée. I am familiar with the traditions of Arab countries and Islamic practices and was able to engage in friendly interactions with participants early on. I was also able to be useful to them, outside of the frame of the resettlement agency, to facilitate access to NGOs and attend meetings with TANF staff. I also accompanied refugees to meetings with employers and doctor's visits where I interpreted for them. Within the first two months I began to be invited to children's birthday parties, women's get-togethers, dinner parties, and other gatherings. As a woman, my relationships were stronger with women, though I also have phone calls and meetings with the men, who call me "Ustazah" or "Okht" - a formal greeting for a woman, or "sister" respectively.

On the question of my proximity to the research sample, I believe that the relationships I developed provided a level of trust that allowed me to have a deeper understanding of respondent's lives facilitating the insights presented in this paper. This trust was regularly tested as resettlement agency staff, with whom I was also friendly, were offended when I did not share with them activities of refugees that broke the rules—-such as working off-the-books. Finally, though I was closely involved in the lives of refugees, and though I am empathetic to their 
experiences, I did not impact the findings that I discuss here. I was careful to document in my field notes anytime I facilitated refugee's access to any resource, usually services offered through local NGOs. The findings of this paper are largely structurally and culturally shaped and I could not change the skills that refugees had when they entered the labor-market, how they managed household labor, or the impacts of the self-sufficiency policy on their lives. I also did not assist in job searches.

For the analysis, I used a grounded theory approach, starting inductively with my data but moving iteratively between data and analysis. I used open coding, that reflected repeated observations in my fieldnotes. I refined my coding and themes through the writing of analytical memos as I was collecting the data (Corbin and Strauss 1990). Themes that I focused on include how men and women divided labor market and caregiving tasks across countries, how they felt about that division, how the self-sufficiency requirement intervened, and how these processes shaped how men and women accessed and felt about English language learning. I also identified "relational work" as a process of interest as a result of observing repeated compensatory strategies among women and men in the sample. Through this analysis, I noted cases that didn't follow emergent patterns, which I include in this paper. Finally, I reached out to my participants, to ask if they perceived the patterns that I was identifying to be true, which they confirmed.

\section{HOUSEHOLD DIVISIONS OF LABOR BEFORE RESETTLEMENT}

I present my findings in three parts. I describe how men and women adjusted their behavior in the constraints of the US context, the ramifications of their adjustment on their gendered formation of human capital and how they made meaning about their behavioral adjustment and 
new resources. Before presenting this analysis, I anchor the shifts in the men and women's histories, describing their behaviors, human capital skills, and self-understandings before travel. Najlaa and Nabil, who arrived in the U.S. with their four children in the winter of 2015, behaved in ways typical to the families in this study. Both grew up in Homs, Syria, where they lived after they were married. Nabil dropped out of school in the third grade to join the family business, becoming a carpenter. Najlaa stayed in school until the ninth grade. The couple was not anomalous in this educational difference. Nabil was the primary breadwinner, he ran errands for the family—managing bureaucracies, doctor's offices, and markets—and he also took the family on regular trips, such as outings on Fridays to local parks or village homes. Najlaa, followed the day-to-day educational progress of her children, and took care of the family home-including budgeting. The men and women did their work in the context of extended family networks whose members were involved in businesses, and lived nearby (Rabo 2008).

As a result of these behaviors, men and women had different sets of capabilities. The men had artisan skills — carpentry, tile laying, or were chefs. The women, meanwhile, had skills tied to their domestic tasks, including cooking. While some women learned handiwork-Rajaa, a mother of three, was taught to crochet by her parents - the women did not use these skills in Syria as income-earning resources. While women had on average a higher level of education than men the level of education that they had acquired (less than a high school level except in two cases), was not helpful for labor-market entry in Syria, which required either a tangible skill - like the ones that the men had—or a post high school educational credential.

The tasks men and women performed and the skills they developed through those tasks were integral to how they saw themselves as spouses and parents. Even in the U.S., when Syrian men met for the first time, they identified themselves in relation to their occupations in Syria; "I 
am an electrician" or "I am a carpenter." This does not mean, however, that these tasks were always easy in Syria. Majid, Rajaa's husband, for instance, had to travel to Saudi Arabia to earn remittances so that he could buy his family property and a house. And while the Najlaa describes her social life in Syria as an "endless tea party," Rajaa remembers feeling oppressed by her inlaws who would intervene in her childrearing.

The taken-for-granted behaviors of the families in this study were disrupted when the Syrian war began in 2011. The majority of people in this study lost loved ones. Nabil was imprisoned and tortured for two months. By 2012, the families had fled to Jordan or Turkey where they lived for an average of 3 years. Everyone in this sample avoided refugee camps for most of that time, using the remnants of their middle-class resources to bribe their way out. In these countries, families struggled to scrape by, and therefore the conditions of their labor were already different than they were in Syria. However, these countries were also seen as temporary solutions to displacement by the families in this study. Resettlement, by contrast, is a permanent solution to displacement; a new beginning. This article examines how Syrian refugees adjusted to what was to be their new forever home- where they knew that their "adat we taqaleed," or norms and traditions, would be challenged.

\section{CONTEXT \& BEHAVIORAL ADJUSTMENT}

As Syrian refugees were resettled in the U.S., they faced new sets of institutions. This section explores how men and women shifted their behavior at this juncture. In this section, I highlight the case of Faten, Ahmed, and their son Ali, who were resettled to Connecticut in November of 2015. In Syria, Ahmed was a consignment store owner, while Faten was a stay-at-home mom, although she was one of two women in this sample who had a high school education. In their 
initial meeting with a resettlement caseworker in Connecticut, the couple, who arrived with no money, asked what kind of assistance they would receive in the U.S. During this meeting, they learned about TANF for the first time. They were told that they would receive $\$ 597$ per month, and that they would receive an additional $\$ 511$ in food stamps, through an Electronic Benefit Transfer (EBT), that could only go towards food items. These numbers surprised Ahmed. "Is this per person or for the whole family?" he asked. The caseworker confirmed that it was for the whole family of three. They also learned that for up to six months the resettlement agency would help them pay their rent. They would put half the TANF benefit towards rent, while the agency would cover the rest.

Two months after the family's arrival, an employment officer from the resettlement agency helped the couple prepare resumes. The officer asked Ahmed to list the skills that he had. Although Ahmed had worked for decades as a small business owner, he was unsure of what he could do in the U.S. Ahmed became frustrated during this meeting asking, with exasperation, how he could find a job without speaking the language? The officer replied sympathetically, "Finding a job in America is like climbing a steep mountain, even for the native-born English speaker." Ahmed, like the other men in this sample, had already been looking for employment since he arrived but had trouble finding work through his social network, comprised mostly of refugees who were as new as he was.

When the officer was done with Ahmed, he turned to Faten. Did she want to prepare a C.V.? Ahmed responded for his wife with an immediate "no" indicating that she would not be working. Faten explained, "I have a child." In that moment, Faten invoked her motherhood as sufficient reason for her to stay out of the labor market. However, she also said to the officer that maybe, in the future, she might be open to a job, after she learned enough English; implying that 
having a child did not preclude her from the labor market, but rather from the labor market that was available to her without the language.

Four months after this meeting, the resettlement agency stopped helping the family with rent, as was the policy. The TANF cash was insufficient to cover the family's $\$ 1,200$ rent, let alone other day-to-day expenses. As the household's breadwinner, Ahmed had to find a job. He became a dishwasher at a pub in a suburban neighborhood. Ahmed felt grateful for the $\$ 1$ over minimum wage he received. Due to the nature of the job, however, he had no control over his shifts, and did not always get full-time work. Though he tried to attend English class, his work schedule was unpredictable. He also did not have the time or energy to study after his shift. This was true of most of the men in this sample. Most initially worked low-wage jobs - dishwashers, janitors, gas station attendants - where coworkers did not speak English and where they did not have the energy or time to attend English classes after work.

Meanwhile, Ali, who was five, was eligible to enroll at a local kindergarten. Without the obligation to take care of Ali during the day, Faten began to attend English class in the morning at the resettlement agency. Because Faten was one of two women who knew some English from Syrian High School she excelled quickly through the lessons. In the fall of 2016, in a move that distinguished her from the other women in this sample, she enrolled a community college, where she took the English as a Second Language (ESL) sequence for two semesters. While Faten studied, she began to interpret for a dentist in her apartment building, when he got Arabicspeaking clients, and began to give cooking classes through a local community group. Both activities were purposefully part-time so that she could take care of Ali after school, and cook and clean for her household. 
Most of the women in this study shared Faten's trajectory. When children were sent to school, or daycare, the women began to attend English class. Most went to class at the resettlement agency whereas some chose to go to a nearby class offered free by the city. Most of the women in this sample, within a year after their resettlement, also took on some kind of income-earning task to support their husbands' income-earning. The women utilized the skills that they had. For example, Rajaa crocheted baby clothes and flower pins. Afaf prepared food for the resettlement organization for arriving families, and also helped conduct cooking lessons through a local non-governmental organization. And, 26-year-old Ghada, whose husband Zafir had said with finality “our wives don't work”- did work. She prepared sweets, Halawit El Laban and Kunafa, that her husband sold to other co-ethnics.

Importantly, the work that the women did as caretakers and their part time income earning was not counted as "work" by TANF, which only counted paid labor for which there is a paystub. Rajaa, for instance, was informed that for her family to continue to be eligible for TANF benefits, she would need to complete a "Work Verification" log, accounting for 35 hours of her week. English language, the caseworker said, would count as "job preparation.” Rajaa would also need to complete an additional 15 hours of "job search." The care work that Rajaa performed for her 9-year-old daughter with Post Traumatic Stress Disorder, or the cooking and cleaning she did each day did not count towards "work." Rajaa's crochet work also did not count, neither did Madiha's sewing or Afaf's cooking for sale. TANF's “Work Verification Plan" clarified that self-employment is "discouraged" because the program requires that the "client participate in other countable activities" (State of Connecticut 2014). While more of the men's work was seen by TANF, the work that they perceived to be a ladder out of poverty, like 
Amjad fixing cars on the side or Majid doing catering gigs was also not "countable." TANF's focus on countable work missed the bulk of family work and particularly women's work.

In summary, men were maintained as primary breadwinners in the Syrian case. Men entered the labor market, but the jobs available to them were menial, and prevented them from attending English class. By contrast, after they secured childcare for their children, the women began to attend English classes, and entered the labor market in a secondary capacity, in parttime work. The following section examines how these behavioral shifts, which occurred due to the requirement for self-sufficiency, poor labor-market conditions, and cultural meanings about men and women's labor within Syrian families and communities, mattered for refugees' development of human capital.

\section{DIVERGENT HUMAN CAPITAL}

Due to the shift in their behaviors, men and women had different opportunities to build their English language ability, a crucial element of human capital for immigrants. I illustrate how human capital was a gendered product of context through the example of Amjad and Rima who arrived in the U.S. with their two toddler sons in the summer of 2015. When their rent assistance ran out, Amjad, like Ahmed, would be the one to enter the labor-market on behalf of the family. Through his next-door neighbor, an Iraqi refugee, he found work as a janitor.

Amjad, who had hoped to work as a contractor as he had in Syria, was frustrated by the lack of prospects this new job offered, and the lack of opportunity he had to learn English in the U.S. He explained,

I want to work. But I am new here. We just got here. We don't understand anything, but you want to push me, tedfeshooni, to work. So, we work whatever, 
hayallah. Most work in restaurants, doing whatever... Everyone is working against their will. No one is happy. In other countries, they allow us to study, to get assistance, they say you're not allowed to work so you can learn. Not here. Amjad compared his resettlement to that of his family in Canada who were supported financially by the government for their first year, with the potential for enrollment in welfare thereafter. Amjad, felt that he was forced by the self-sufficiency imperative into a dead-end factory job. He explained, "The factory that I'm working at, even if I worked the rest of my life there, I am not going anywhere." At work, Amjad could not speak to his colleagues and was isolated for most of the day. A year into working there, his English had not improved. The men in this study could only find employment where English language communication was not a necessity, and therefore colleagues were often not English speakers.

Amjad supplemented his income by working off-the-books. He fixed the cars of other Arabs, hoping that he could someday turn this into a full-time business. But, he would need to acquire enough money to rent a shop and get equipment. Unlike the immigrants of an earlier time, who earned living wages, Amjad had few opportunities to build economic capital (Gans 1992). Meanwhile, Amjad's hours at work meant that he could not go to his children's school in the case of an emergency or take them to their medical appointments, things that he could do in Syria where he owned his own shop; i.e. he could not to do the tasks he once did as a father.

As a result, his wife, Rima began to run errands on behalf of her household even though she had little mobility in either Syria and Jordan (out of all of the women in the study, Rima grew up in the most conservative family). Once both of Rima's boys had gone to kindergarten and the daycare at the resettlement agency respectively, Amjad encouraged his wife to become more mobile asking, "What if something happens to the kids while I'm at work?" Rima was still 
the primary childcare provider for the family, and still took care of day-to-day domestic tasks of cooking and cleaning. This was true for all of the women in this sample. However, once her children were placed in daycare, encouraged by her ability to navigate the bus system, Rima began to attend English classes.

Rima, sitting among refugee men and women from different countries, attended English class at the resettlement agency each morning, gaining language, a skill that would matter in four ways. First, Rima was able to communicate with service providers-like her son's teacher or the resettlement agency — though at a rudimentary level. These are tasks that her husband, without any English, was unable to do. Second, this ability to communicate in basic English reduced isolation among the women in this study, as anticipated by other research (Nawyn 2011). It facilitated buying groceries, getting on the bus, paying bills, and accessing service providers. Third, it facilitated expansion of social networks. Rajaa was able to communicate with Betty, a woman who volunteered with the resettlement agency. Betty taught Rajaa to make chocolate chip cookies, and later, when Rajaa began to think of her crochet work as an income-generating activity, secured Rajaa donated yarn. Finally, the women were also working towards the citizenship exam, offered only in English, for which they'd be eligible in five years. Citizenship would reinstate families' full legal rights that they had lost in their country's war, enabling them to visit loved ones in the diaspora, and entitling them to begin reunification petitions for family to join them in the U.S.

Importantly, one anomalous case, of Zacherya, 32, underscores the significance of the policy system and the labor market in determining this human capital divergence. When he was in Turkey with his wife, Narjis, they were approached by a famous photographer. Their photo went viral, and the photographer was able to raise $\$ 50,000$ on their behalf. In addition, the family 
also received disability assistance due to their older son's chronic health condition. Due to this support, Zachareya was able to stay out of the labor market for the first year, taking English classes in the morning and evening. In this way, his case mimicked the assistance received by refugees in Canada, where there is an "integration" rather than self-sufficiency logic that allows refugees to stay out of the labor market for at least their first year of resettlement. However, because there was no childcare assistance for their disabled son, this came at the expense of Narjis who stayed home to care for him. When Zachaerya finally entered the labor market, a year after the family's resettlement, he was hired full-time at a wax factory earning well-above minimum wage in a job with benefits. This meant that the family's experience of poverty was greatly reduced which benefited both Zachareyah and Narjis. This anomalous case of Zachareya confirms that the way that men and women reorganize labor, and the ramifications of that reorganization, is a result of the context of reception in which they are incorporated.

In summary, as men and women took on new behaviors in immigration, they diverged in their ability to develop basic language ability. Language ability was immediately a crucial resource for the family - it reduced isolation by allowing communication with service providers and non co-ethnics. In this way, I argue that human capital is a gendered relational product of household divisions of labor in immigration.

\section{MAKING MEANING OF SHIFTING LABOR}

Though men and women took on new behaviors, and accessed new resources, they also held on to cultural expectations for their labor. First, the experiences of Najlaa and Nabil, who are illustrative outliers, clarifies that men were reinforced as primary breadwinners in part because women did not want to enter the full-time labor-market in their early resettlement. They did not 
want to work menial jobs that they would be embarrassed by, but also that their community—of formerly middle-class Syrians_-frowned upon.

Two months after their arrival in the U.S., Nabil was diagnosed with cancer. He had to undergo chemotherapy and would not be able to work for the foreseeable future. After helping the family pay rent for their first year, the resettlement agency was forced by budget cuts to withdraw their support. Najlaa found herself having to become the primary breadwinner. She was devastated by this prospect. "What kind of job can I work?” she asked, referencing her lack of English ability, and middle-school education. While she may have been able to find an opportunity working at a restaurant with co-ethnic men (no women worked at these places) she avoided these business, because she was worried about "what people would say." Her husband threatened to quit chemotherapy, wanting to prevent his wife from taking on this kind of public, menial labor. She preferred to work somewhere that co-ethnics would not see. She was able to find cleaning work, a job characterized by diminished physical autonomy. She took this job without telling anyone.

Najlaa's fear of social sanction is also illustrated in the case of Wedad. When her husband Fawaz, a former government worker, refused to enter the labor-market, feeling that the jobs offered were beneath him — the only man in this study to take such a stand - Wedad found a job working shifts in food preparation at a hospital. Fawaz's aversion to work, and his willingness to allow his wife to work in his stead, lead a co-ethnic man to ask rhetorically, "What is wrong with this man?” Moreover, Najlaa's concerns over the low caliber nature of jobs available to her, were echoed by Rajaa. When she was asked by an NGO if she wanted a fulltime opportunity. "I'm not going to lie to you," she told me, "I don't want to be in a situation where I'm out there the way he [Majid her husband] is. I am not used to it." 
Women also reinforced men as primary breadwinners because the full-time job prospects available to them would not allow them to perform care work. Rajaa wanted to be home for her daughter, who suffered from PTSD and separation anxiety, after school. Working full-time, as her husband did, would not allow her this ability. Najlaa similarly had four kids and was concerned about who would be able to take care of them. Her husband was ill. If she worked full-time, the responsibility to take care of her children would fall on the shoulders of her 12year-old daughter, something she did not want for her. The lack of social service support, and labor laws that recognize care work as a crucial part of people's lives, resulted in these trade-offs that contributed to women's resistance to entering the labor market, resonating with other literature on women's labor market pathways (Damaske 2011).

The women in this study did work part-time. As Rajaa explained, "In Syria I took care of the house and he earned the money. Here I have to help him out. He can't do it on his own." In light of this necessity, the maintenance of men as primary breadwinners involved relational work, including earmarking earnings. For instance, When Majid worked a catering job, with Rajaa's help, he determined that his earnings would be spent on rent, though Rajaa wanted to buy new beds for their children. However, when she earned money through crocheting, that was her money to spend. The next day the couple drove to Ikea to look for the beds. Given their poverty, however, women's retention of their own income was not always an option. For instance, Sara, who earned money selling cookies, paid for her husband's traffic ticket with her earnings, since they had no other choice. He, however, apologized profusely that she had to spend "her" earnings on him, whereas the opposite would be commonplace. This position of women's earnings in the household both gave women heightened decision-making authority over 
their earnings, while also casting them as supplementary, thereby maintaining the notion that men are the primary household breadwinners.

In this process, the English that women were learning was imagined as a resource that would result in futures where they could enter the labor market in high status jobs. Sarah, for instance, expressed a desire to secure her GED. She contemplated the possibility that she could go to college and secure a high-paying job one day. Narjis, in a phone call with her mother who was back in Syria, told her that she wanted to "become a doctor" which lead to an international game of telephone that ended in congratulations from her cousins.

And, in Faten's case, the one case where a woman was able to learn enough English to use it in a labor market setting, the discrepancy between her and her husband's labor market participation became an emotional issue. Faten felt that she had "left him behind" since she was earning college credits, and working as an interpreter, while he was washing dishes. But still, they maintained him as the primary income-earner, and her as the primary care taker. When Faten was annoyed with Ahmed she wondered why she "helped" him come up with extra income saying, "I should just let him fend for himself." And, when she went out to her interpreter work, Ahmed "helped" her take care of their son, not seeing that as his primary role.

In sum, men were reinforced as primary breadwinners and women as primary caretakers, even as they took on new behaviors and built new resources. Where men and women were unable to maintain these distinctions, there were difficult emotional consequences. These findings clarify the importance of the relational approach for capturing the ways in which meanings shape how men and women interpret and changes in behaviors and resources.

\section{CONCLUSION}


Shifts in context, whether due to transnational immigration or economic transformations, challenge gendered divisions of labor within households (Hondagneu-Sotelo 1992). Globally, studies show that even when men and women's behaviors shift in new contexts, cultural expectations are slow to follow (Ashwin 2018; Pierotti and Milli 2018). The reinforcement of cultural expectations can result in a "second shift" of care work and paid work for women, or the discounting of women's earnings as supplementary, diminishing women's access to resources of time, money, and decision-making power within households (Anderson 2017; Hochschild 1989). From the vantage of Syrian refugees, in their initial years of resettlement, this study explores a counterintuitive finding, whereby maintaining cultural expectations for men and women's labor resulted in a divergence in the production of a crucial resource benefiting women: human capital in the form of language learning.

To understand this outcome, is to examine the complexities of context, and how it shapes how gender is "done" (Duffy 2007; Hoang 2016). Contexts in receiving countries are treated by a mainstream immigration literature as a set of institutions - labor markets, laws, social networks - that all immigrants encounter upon arrival (Portes and Rumbaut 2014). But, these institutions entail inequalities that intersect to produce different environments for people across the demographic spectrum, including for women and men (Damaske 2011; Flippen 2014; Mahler and Pessar 2006). In the case of Syrian refugees, it was at the intersection of precarious job opportunities for new market entrants, a social service policy that aimed for "self-sufficiency," and cultural expectations for men and women's labor within the household that Syrian refugee men and women diverged in their use of time and ability to build human capital. Men, maintaining cultural expectations as primary breadwinners, entered menial jobs that truncated 
their ability to attend English classes. Women, by contrast, in taking on secondary and part-time jobs, were able attend these courses gaining a crucial human capital.

While this paper centers a unique case of newcomer Syrians who happen to be Arabs, Muslims and refugees (all understudied groups), its findings are widely applicable. Identifying human capital as a gendered outcome of immigration, produced in the context of intersecting inequalities, is a notable departure from immigration literature that treats human capital as a determinant of immigrant outcomes (Luthra, Soehl, and Waldinger 2017; Portes and Rumbaut 2014). By counting years of education or years of employment experience, these studies obscure how receiving contexts act on immigrant's ability to express and gain meaningful skills in a new economy, and how this process is gendered. Beyond pointing to human capital as a gendered product of immigration, this study also calls for an examination of the ways in which women may gain resources in new contexts, even as other inequalities are maintained.

Finally, by focusing on the experience of refugees who in their early resettlement, and who have access to social services, this paper captures how low-income minorities are produced at the intersection of labor-markets and social services in the U.S. (Hays 2003; Lein and Edin 1997). Full-time work in low-skilled jobs is characterized by shift-work and long hours that do not ensure a living wage, and limit workers' ability to gain skills necessary to compete in the contemporary labor market (Kalleberg 2011). Social services, meanwhile, are built on racialized and gendered notions of the dependency of the poor that limit the amounts of assistance offered (Katz 2013; Shola Orloff 2009). Together, these systems push the poor into the labor-market, unsupported by a safety net, while ignoring persistent drivers of poverty: skill deficits, health and care work burdens, and poverty wages. Child care, offered privately through the resettlement agency in the case of Syrians, was the crucial resource that allowed women in this study to learn 
English. In this way, through the experiences of these new arrivals, the paper highlights the deficiencies of a system long traversed by low-income men and women in the U.S. 


\section{Bibliography}

Allen, Ryan. 2009. "Benefit or Burden? Social Capital, Gender, and the Economic Adaptation of Refugees.” International Migration Review 43(2):332-65.

Anderson, Nadina L. 2017. "To Provide and Protect: Gendering Money in Ukrainian Households." Gender \& Society 31(3):359-82.

Ashwin, Sarah. 2018. “Anatomy of A Stalled Revolution: Processes of Reproduction and Change in Russian Women’s Gender Ideologies.” Gender \& Society 32(4):441-68.

Bandelj, Nina. 2012. "Relational Work and Economic Sociology.” Politics \& Society 40(2):175201.

Becker, Gary S. 1985. "Human Capital, Effort, and the Sexual Division of Labor." Journal of Labor Economics 3(1, Part 2):S33-58.

Blair-Loy, Mary. 2009. Competing Devotion : Career and Family among Woman Excecutive. Harvard University Press.

Blau, Francine D., Lawrence M. Kahn, and Kerry L. Papps. 2011. “Gender, Source Country Characteristics, and Labor Market Assimilation among Immigrants.” Review of Economics and Statistics 93(1):43-58.

Connell, Raewyn and James W. Messerschmidt. 2005. "Hegemonic Masculinity.” Gender \& Society 19(6):829-59.

Corbin, Juliet and Anselm Strauss. 1990. Grounded Theory Research: Procedures, Canons, and Evaluative Criteria.

Damaske, Sarah. 2011. For the Family? How Class and Gender Shape Women's Work. Oxford University Press. 
Dreby, Joanna. 2006. "Honor and Virtue: Mexican Parenting in the Transnational Context." 20(1):32-59.

Duffy, Mignon. 2007. "Doing the Dirty Work: Gender, Race, and Reproductive Labor in Historical Perspective.” Gender \& Society 21(3):313-36.

Edin, Kathryn J. and H. Luke Shaefer. 2015. \$2.00 a Day: Living on Almost Nothing in America. Houghton Mifflin Harcourt.

England, Paula et al. 2010. "The Gender Revolution Uneven and Stalled.” Gender and Society 24(2):149-66.

Espiritu, Yen Le. 2001. “'We Don’t Sleep Around Like White Girls Do’: Family, Culture, and Gender in Filipina American Lives.” Signs 26(2):415-40.

Ferree, Myra Marx. 1979. "Employment without Liberation: Cuban Women in the United States." Social Science Quarterly 60(1):35-50.

Flippen, Chenoa A. 2014. "Intersectionality at Work: Determinants of Labor Supply among Immigrant Latinas." Gender \& Society 28(3):404-34.

Frank, Kristyn and Feng Hou. 2015. "Source-Country Gender Roles and the Division of Labor within Immigrant Families.” Journal of Marriage and Family 77(2):557-74.

Gans, Herbert. 1992. "Second-generation Decline: Scenarios for Theeconomic and Ethnic Futures of the Post-1965American Immigrants.” Ethnic and Racial Studies 15(2):173-92.

Golash-Boza, Tanya and Pierrette Hondagneu-Sotelo. 2013. "Latino Immigrant Men and the Deportation Crisis: A Gendered Racial Removal Program.” Latino Studies 11(2013). Government of Canada. 2016. “Government-Assisted Refugee Program.” Government of Canada. Retrieved March 13, 2017 (http:/www.cic.gc.ca/english/refugees/outside/resettlegov.asp). 
Halpern, Peggy. 2008. "Refugee Economic Self-Sufficiency: An Exploratory Study of Approaches Used in Office of Refugee Resettlement Programs." US Department of Health and Human Services.

Hays, Sharon. 2003. Flat Broke With Children: Women in the Age of Welfare Reform. Oxford University Press.

Hoang, Lan Anh. 2016. "Moral Dilemmas of Transnational Migration: Vietnamese Women in Taiwan.” Gender \& Society 30(6):890-911.

Hochschild, Arlie. 1989. The Second Shift. Viking Adult.

Hondagneu-Sotelo, Pierrette. 1999. “Gender and Immigration: A Retrospective and Introduction." in Gender and US Immigration: Contemporary Trends, edited by P. Hondagneu-Sotelo. University of California Press.

Hondagneu-Sotelo, Pierrette. 1992. "Overcoming Patriarchal Constraints: The Reconstruction of Gender Relations Among Mexican Immigrant Women and Men.” Gender \& Society $6(3): 393-415$.

Hondagneu-Sotelo, Pierrette. 2013. "New Directions in Gender and Immigration Research.” Pp. 233-45 in International Handbook on Gender, Migration and Transnationalism, edited by L. Oso and N. Ribas-Mateos. Edward Elgar Publishing.

Kalleberg, Arne L. 2011. Good Jobs, Bads Jobs: The Rise of Polarized and Precarious Employment Systems in the United States. Russel Sage Foundation.

Katz, Michael. 2013. The Undeserving Poor: America's Enduring Confrontation with Poverty: Fully Updated and Revised. Oxford University Press.

Khazan, Olga. 2012. "Who's Fighting Whom in Syria?" The Washington Post. Retrieved October 12, 2016 
(https://www.washingtonpost.com/news/worldviews/wp/2012/10/18/whos-fighting-who-insyria/).

Kibria, Nazli. 1993. Family Tightrope: The Changing Lives of Vietnamese Americans. Princeton, New Jersey: Princeton University Press.

Lein, Laura and Katherine Edin. 1997. Making Ends Meet: How Single Mothers Survive Welfare and Low-Wage Work. Russel Sage Foundation.

Luthra, Renee, Thomas Soehl, and Roger Waldinger. 2017. "Reconceptualizing Context: A Multilevel Model of the Context of Reception and Second-Generation Educational Attainment.”

Mahler, Sarah J. and Patricia R. Pessar. 2006. “Gender Matters: Ethnographers Bring Gender from the Periphery toward the Core of Migration Studies." International Migration Review 40(1):27-63.

Nawyn, S. J., L. Gjokaj, D. L. Agbenyiga, and B. Grace. 2012. “Linguistic Isolation, Social Capital, and Immigrant Belonging." Journal of Contemporary Ethnography 41:255-82.

Nawyn, Stephanie J. 2011. “I Have so Many Successful Stories’: Framing Social Citizenship for Refugees." Citizenship Studies 15(6-7):679-93.

Park, Haeyoun and Rudy Omri. 2016. "U.S. Reaches Goal of Admitting 10,000 Syrian Refugees. Here's Where They Went." New York Times2, August 31.

Parrado, Emilio and Chenoa A. Flippen. 2005. "Migration and Gender among Mexican Women.” American Sociological Review 70:606-32.

Parreñas, Rhacel Salazar. 2001. Servants of Globalization : Women, Migration and Domestic Work. Stanford University Press.

Pessar, Patricia. 1986. “The Role of Gender in Dominican Settlement in the United States.” Pp. 
273-94 in Women and Change in Latin America.

Pessar, Patricia R. and Sarah J. Mahler. 2003. "Transnational Migration: Bringing Gender In.” International Migration Review 37(3):812-46.

Pierotti, Rachael and Usa Milli. 2018. "Equality on His Terms: Doing and Undoing Gender through Men's Discussion Groups." Gender \& Society 32(4):540-62.

Portes, Alejandro and Ruben G. Rumbaut. 2014. Immigrant America: A Portrait. University of California Press.

Rabo, Annika. 2008. “'Doing Family': Two Cases in Contemporary Syria.” Journal of Women of the Middle East 6:129-53.

Ridzi, Frank. 2009. Selling Work-First. New York University Press.

Shola Orloff, Ann. 2009. "Gendering the Comparative Analysis of Welfare States: An Unfinished Agenda*." Sociological Theory 27(3):317-43.

Silver, Hilary. 1993. “Homework and Domestic Work.” Sociological Forum 8(2):181-204.

State of Connecticut. 2014. Temporary Assistance for Needy Families (TANF) Work Verification Plan.

Tilly, Chuck Charles. 2006. Why? What Happens When People Give Reasons and Why. Princeton University Press: Princeton University.

UNHCR. 2016. "Syria Regional Refugee Response - Regional Overview.” Inter-Agency Information Sharing Portal. Retrieved October 11, 2016 (http://data.unhcr.org/syrianrefugees/regional.php).

United States Congress. 1980. Refugee Act United States of America.

West, Candace and Don Zimmerman. 1987. "Doing Gender." Gender and Society 1(2):125-51.

West, Candace and Don H. Zimmerman. 2009. “Accounting for Doing Gender.” Gender \& 
Society 23(1):112-22.

Zelizer, Viviana. 1997. The Social Meaning of Money. Princeton: Princeton University Press. Zelizer, Viviana A. 2012. "How I Became a Relational Economic Sociologist and What Does That Mean?" Politics \& Society 40(2):145-74.

Heba Gowayed is a postdoctoral fellow in the sociology department at Columbia University. Her research interests include gender, race, immigration, and social policy. 